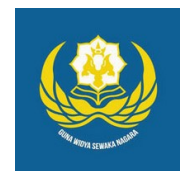

Jurnal Analogi Hukum

Journal Homepage: https://ejournal.warmadewa.ac.id/index.php/analogihukum

\title{
Tinjauan Yuridis Terhadap Tindak Pidana Perkosaan Dalam Perspektif Hak Asasi Manusia
}

\author{
Kadek Dwi Novitasari*, Ida Ayu Putu Widiati Dan I Nengah Laba \\ Fakultas Hukum, Universitas Warmadewa, Denpasar, Bali-Indonesia \\ *dwinovita@gmail.com
}

\begin{abstract}
How To Cite:
Novitasari, K. D., Widiati, I. A. P., \& Laba, I. N. (2020). Tinjauan Yuridis Terhadap Tindak Pidana Perkosaan Dalam Perspektif Hak Asasi Manusia. Jurnal Analogi Hukum. 2(3). 388-392. Doi: https://doi.org/10.22225/ah.2.3.2501.388-392

Abstract-Rape crime is the most common case in Indonesia. Rape is a crime that is very cruel, immoral, despicable and violates the norm where the victims are women both adults and minors. Rape violates Human Rights especially for women. The formulation of the problem raised is how to protect the law of women who are victims of rape in the perspective of human rights and how criminal sanctions are applied to perpetrators of rape crimes. This type of research is a research with a legal and conceptual problem approach. The results of this study indicate that legal protection that can be given to women who are victims of acts of sexual violence / harassment is stipulated in Article 285 of the Criminal Code and Law No. 13 of 2006 specifically in Article 5, Article 8, and Article 9 which are generally in the form of protection and rights of witnesses and victims. Victims of sexual violence have rights that must be enforced, hurt, suffering, fear, and various kinds of adverse effects that befall him after rape and need serious attention. While criminal sanctions against perpetrators of criminal acts of rape have been regulated in general in Article 285 of the Criminal Code which faces a sentence of twelve years in prison.
\end{abstract}

Keywords: Crime; Rape; Human Rights

\begin{abstract}
Abstrak - Tindak pidana perkosaan merupakan kasus yang paling banyak terjadi di Indonesia. Perkosaan merupakan suatu tindak kejahatan yang sangat keji, amoral, tercela dan melanggar norma dimana yang menjadi korban adalah perempuan baik dewasa maupun anak di bawah umur. Perkosaan melanggar Hak Asasi Manusia (HAM) khususnya bagi kaum perempuan. Adapun rumusan masalah yang diangkat adalah bagaimana perlindungan hukum terhadap perempuan yang menjadi korban perkosaan dalam perspektif hak asasi manusia dan bagaimana sanksi pidana yang diterapkan terhadap pelaku tindak pidana perkosaan. Jenis penelitian ini merupakan penelitian dengan pendekatan permasalahan perundang-undangan dan konseptual. Hasil penelitian ini menunjukkan bahwa perlindungan hukum yang dapat diberikan terhadap perempuan yang menjadi korban tindak kekerasan/pelecehan seksual diatur dalam Pasal 285 KUHP dan Undang-Undang No. 13 Tahun 2006 khususnya dalam Pasal 5, Pasal 8, dan Pasal 9 yang secara umum berupa perlindungan dan hak saksi dan korban. Korban tindak kekerasan seksual memiliki hak-hak yang wajib ditegakkan, rasa sakit hati, penderitaan, ketakutan, dan berbagai macam dampak buruk yang menimpa dirinya pasca perkosaan dan perlu mendapat perhatian serius. Sedangkan sanksi pidana terhadap pelaku tindak pidana perkosaan telah diatur secara umum dalam Pasal 285 KUHP yang diancam hukuman dua belas tahun penjara.
\end{abstract}

Kata kunci: Tindak Pidana; Perkosaan; Hak Asasi Manusia

\section{Pendahuluan}

Di Indonesia ada berbagai bukum yang berlaku yaitu salah satunya hukum pidana. Di antara semua manusia yang sangat rawan menjadi korban kejahatan adalah perempuan. Dalam bidang kesusilaan yang sangat sering menjadi korban kejahatan adalah perempuan. Perepmpuan saat ini sedang menjadi objek pengibrian serta pelecehan hak-haknya. Nilainilai kesusilaan yang sepantasnya dijaga kemurniannya sedang dikoyak dan dinodai dengan naluri kebinatangan yang diberikan posisi untuk berlaku sebagai adidaya. Kekerasan, pelecehan, dan eksploitasi seksual tidak hanya menimpa kaum perempuan dewasa saja, namun perempuan yang tergolonh di 
bawah umur. Kejahatan seksual juga tidak hanya berlangsung di kawasan perkantoran atau tempat-tempat teretntu (Wahid, 2001).

Bentuk kekerasan primitive yang kita tahu semua terdapat pada masayrakat manapun. Tindak pidana kejahatan perkosaan adalah salah satu kejahatan yang harus di pikirkan secara serius. Dari dulu sampai sekarang, kejahatan perkosaan tidak hanya kekerasan sex semata, tetapi merupakan suatu prilaku yang di pengaruhi dalam sistem kekuasaan tertentu. Oleh karna itu pandangan masayrakat dalam menilai kejahatan perkosaan merupakan cerminan nilai-nilai masyarakat, agama, adat dan lembaga-lembaga besar seperti Negara (Gosita, 2001).

Tindak pidana perkosaan dapat kita ketahui banyak dalam media masa. Kejahatan perkosaan jauh lebih banyak terjadi sebenarnya dari pada yang di beritakan oleh media masa dan yang dilaporkan kepada polisi. Kebanyakan kasus yang terbongkar setelah korban mendapatkan gejala fisik yang serius seperti pendarahan di vagina korban. Masih banyak ada kasus yang tdiak menimbulkan trauma fisik tetapi dapat berdampak srius pada psikologis korban. Tindak pidana perkosaan telah melanggar Hak Asasi Manusia bagi kaum perempuan.

Pada penelitian sebelumnya, (Idran, 2011) mengungkapkan perbuatan tindak pidana perkosaan terhadap anak kandung sebagaimana dakwaan jaksa penuntut umum melanggar ketentuan Pasal 81 Ayat 1 Undang-Undang Nomor 23 tahun 2002 Tentang Perlindungan anak Jo Pasal 64 Ayat (1) KUHP, dimana dalam pertimbangan hakim dalam putusannya menyatakan, hal yang memberatkan adalah perbuatan terdakwa telah menghancurkan masa depan saksi korban, sedangkan tidak ada alasan yang meringankan bagi terdakwa. Penelitian lainnya oleh, (Ruben, 2019) mengungkapkan dalam hukum pidana ketentuan yang bisa menjerat pelaku tindak pidana pemerkosaan disertai pembunuhan anak dibawah umur adalah dalam pasal Pasal 287 Ayat (1) KUHP tentang pemerkosaan anak di bawah umur lima belas tahun dengan ancaman pidana paling lama sembilan tahun, dan juga Pasal 338 KUHP tentang kejahatan terhadap nyawa dengan ancaman paling lama 15 tahun penjara

Berdasarkan uraian diatas, penulis merumuskan dua permasalahan, yaitu: Perlindungan Hukum yang Menjadi Korban Perkosaan Dalam Perspektif Hak Asasi Manusia Dan Sanksi Pidana yang Diterapkan Terhadap Pelaku Tindak Pidana Perkosaan.
Tujuan khusus dari penulisan penelitian ini adalah Untuk memahami lebih mendalam mengenai perlindungan hukum bagi korban perkosaan dan Untuk memahami sanksi pidana yang dijatuhkan terhadap pelaku yang melakukan tindak pidana perkosaan.

\section{Metode}

Dalam suatu penulisan karya ilmiah, agar karya ilmiah tersebut memiliki bentuk penulisan yang tersusun secara sistematis, terarah dan konsisten dalam memperoleh dan menganalisis bahan hukum yang bersifat ilmiah. Adapun metode yang dipakai di dalam penelitian ini yaitu:

Tipe penelitian hukum normative, yaitu pengkajiannya dengan berdasarkan bahanbahan hukum dari literature. Pendekatan perundang-undangan dan pendeketan konseptual, pendekatan perundang-undangan dilakukan dengan cara menelaah semua peraturan perundang-undangan yang berkaitan dengan permasalahan yang akan dibahas dalam penelitian ini, sedangkan pendekatan konseptual merupakan pendekatan yang beranjak dari pandangan-pandangan yang berada dalam ilmu hukum guna memperjelas gagasan mengenai definisi dari ilmu hukum, konsep dari hukum serta asas hukum yang signifikan dengan masalah yang akan dibahas dalam penelitian ini. Di dalam penyusunan penelitian ini, menggunakan bahan hukum yang didapat dari penelitian kepustakaan, yaitu: Bahan hukum primer dan Bahan hukum sekunder, bahan hukum primer yaitu terdiri dari peraturan perundang-undangan yang berkaitan dengan tindak pidana perkosaan, sedangkan bahan hukum sekunder yaitu memberikan penjelasan mengenai bahan hukum primer misalnya, seperti buku ilmu hukum, jurnal ilmu hukum serta pendapat dari para sarjana hukum.

Pengumpulan bahan hukum dilakukan dengan cara menginventarisasikan buku-buku dan aturan hukum yang sesuai dengan persoalan yang di telaah. Di dalam penulisan penelitian ini, analisis bahan hukum yang terkumpul menggunakan metode deskriptif yaitu dengan menyusun bahan-bahan hukum yang telah dipilih secara sistematis sehingga membentuk suatu karya ilmiah.

\section{Hasil Dan Pembahasan}

\section{Perlindungan Hukum Terhadap Korban Perkosaan Dalam Perspektif Hak Asasi Manusia}

Secara sosiologis perkosaan merupakan 
tindak pemaksaan terhadap perempuan untuk melakukan hubungan kelamin diluar perkawinan, kemudian kemaluan dari wanita yang berhubungan tidak wajar antara kedua bagian kelamin tersebut menimbulkan rasa sakit karena luka pada wanita (Topo, 1997).

Selaku perempuan yang menjadi korban kejahatan perkosaan telah mendapatkan perlindungan Hak Asasi Manusia. apabila membicarakan tentang Hak Asasi Manusia maka akan dapat memasuki bidang yang sangat luas dan ketakjelasan batas-batas yang terkadung didalamnya.

Hak Asasi Manusia merupakan hak yang dianugrahkan langsung oleh Tuhan Yang Maha Esa sebagai hak yang sangat kodrati. Keterkaitan antara tindak pidana dengan hak asasi manusia yaitu setiap tindak pidana dari peristiwa, delik, dan perbuatan yang sewaktuwaktu dapat menimbulkan terjadinya kejahatan atau pelanggaran hak asasi manusia. Perempuan merupakan korban kejahatan perkosaan yang menjadi salah satu tolak ukur pelanggaran HAM yang paling parah.

Berbagai faktor yang dapat menyebabkan terjadinya tindak pidana perkosaan. Salah satunya dapat dipengaruhi dengan kondisi yang mendukung, secara tidak langsung keberadaan korban mendorong pelaku untuk berbuat keji dan bisa juga karena terdapatnya unsur-unsur lain yang mempengaruhinya. Kejahatan perkosaan dapat terjadi kepada siapapun, termasuk perempuan yang berpakaian serba tertutup atau perempuan yang sudah memiliki anak, bisa juga terjadi kepada wanita yang sedang mengandung, bahkan anak-anak dibawah umurpun dapat menjadi korban perkosaan.

Seseorang yang melakukan kejahatan perkosaan dapat dilihat dari faktor internal yaitu dapat disebabkan oleh mental kepribadian sesorang yang kurang baik, sehingga bisa untuk melakukan kejahatan. Mental kepribadian ini dapat dilihat dari bebrapa faktor anatara lain: faktor pergaulan, agama, lingkungan, pendidikan, dan ekonomi. Sedangkan faktor eksternal seseorang melakukan kejahatan perkosaan dapat dilihat dari faktor korban, perekonomian, dan faktor penggunaan narkotika.

Perempuan yang menjadi korban kejahatan perkosaan dapat diberikan perlindungan hukum melalui KUHP yang mnyangkut dengan perkosaan Pasal 285 KUHP. Korban yang menjadi tindak pidana perkosaan memiliki hakhak yang sangat wajib untuk ditegakkan. Dan korban tidak boleh membiarkan dirinya sendiri memperjuangkan nasib yang telah menimpanya tetapi wajib dilindungi oleh penegak hukum dalam memperjuangkan nasib korban tindak pidana perkosaan. Meskipun hak asasi manusia adalah hak dasar secara kodrat melekat pada diri manusia sejak lahir sehingga harus selalu dilindungi, dipertahankan, dihormati dan dihargai oleh siapapun itu.

\section{Sanksi Pidana Terhadap Pelaku Tindak Pidana Perkosaan}

Dapat dikatakan bahwa sanksi pidana yakni, suatu akibat hukum yang dikenakan terhadap pelaku tindak pidana yang melakukan perbuatan melawan hukum dan perbuatan melawan hukum tersebut bisa merugikan diri sendiri maupun orang lain, atau suatu penderitaan yang diberikan kepada orang yang bersalahdengan melakukan perbuatan yang dilarang terhadap hukum pidana (Ali, 2011).

Penerapan sanksi pidana terhadap pelaku kejahatan sudah merupakan cara terbaik untuk menegakan keadilan. Aparat penegak hukum harus lebih memperhatikan terhadap korban yang menjadi korban kejahatn yang tidak hanya dapat menimbulkan penderitaan fisik, tetapi juga mental dan psikis. Sangat diperlukan penegakan hukum yang sangat maksimal yang dapat meimbangi sanksi hukum yang berat demi mendapatkan nilai keadilan.

Bagi pelaku kejahatan perkosaan harus mendapatkan hukum yang sangat berat supaya para pelaku merasakan efek jera dengan apa yang diperbuat. Sanksi pidana yang dapat diterapkan terhadap pelaku dapat kita lihat sesuai dengan perbuatannya yakni, dalam Pasal 285 KUHP yang memiliki unsur-unsur sebagai berikut: 1) barang siapa, istilah unsur barang siapa yaitu menunjuk kepada siapapun yang dapat dikenakan unsur ini, yang dimaksud dengan barang siapa yaitu lelaki atau pria yang bersetubuh dengan dia. 2) dengan kekerasan atau ancaman kekerasan, yang dimaksud seseorang melakukan kekerasan yaitu dapat membuat orang menajdi tidak berdaya lagi atau pingsan, maka seorang perempuan hanya dapat dikatakan diperkosa saat terhadap tubuh wanita itu terdapat bekas-bekas luka atau pakaian yang dipakai oleh wanita tersebut robek. 3) memaksa, perbuatan yang memaksa dapat dilakukan dengan perbuatan dan dapat juga dilakukan dengan kata-kata atau ucapan. 4) perempuan yang bukan istrinya, dalam unsur keempat dari tindak pidana perkosaan adalah perempuan yang bukan istrinya, sehingga jika terhadap itrinya sendiri maka tidak akan 
dikenakan pasal ini. 5) bersetubuh, dimaksud dengan unsur ini yaitu anggota kelamin pria harus sudah masuk ke dalam vagina si wanita sedemikian rupa, sehingga akhirnya telah mengeluarkan mani. 6) dengan dia, yang dimaksudkan dengan dia adalah kata dengan dirinya itu sendiri orang yang melakukan kekerasan atau ancaman kekerasan yang telah memaksa perempuan yang bukan istrinya untuk bersetubuh dengan dia (Sugandhi, 1980).

Dari unsur-unsur Pasal tersebut maka dapat dibuktikan di dalam sidang pengadilan, walaupun memang harus kita akui bahwa pembuktian ini tidaklah suatu hal yang gampang bahkan seringkali menjadi kendala saat menghukum pelaku yang melakukan tindak pidana.

Pemerintah yang sebagai penyelenggara negara yang seharusnya bertanggung jawab penuh dalam memberikan perlindungan hukum bagi warganya, termasuk dalam hal ini juga pemerintah juga memberikan perlindungan terhadap pelaku kejahatan perkosaan. Dengan demikian haruslah pemerintah melakukan segala upaya untuk mengambil langkah-langkah kebijakan yang diperlukan untuk mengatasi permasalahan tindak pidana perkosaan tersebut.

Walaupun selama ini sudah banyak upaya yang dilakukan, tetapi kenyataannya belum cukup efektif, terbukti dengan masih banyak kasus-kasus kejahatan perkosaan yang telah dilaporkan. Adapun kebijakan kriminalisasi yang telah diupayakan terhadap beberapa bentuk kejahatan perkosaan misalnya memang sudah dilakukan tetapi hal itu sebenarnya hanya salah satu bagian dari langkah-langkah penanggulangan yang bisa dilakukan.

Mengenai kebijakan criminal ini, yang dalam hakikatnya dikenal mempunyai berbagai cara yang pada umunya untuk menaggulangi kejahatan serta khusunya juga pada kejahatan kekerasan seksual. Dalam menanggulangi suatu kejahatan bisa dilakukan dengan berbagai sarana yakni saran hukum pidana (penal) dan sarana non-hukum pidana (non penal).

Dalam upaya penal untuk penanggulangan tindak pidana perkosaan, supaya lebih komprehensif maka perlu adanya untuk diperjelas dalam mengenai garis-garis kebijakan hukum pidana yang terkait dengan kejahatan perkosaan.

Dalam rancangan undang-undang kejahatan seksual yang dalam kebijakannya melindungi korban sangatlah penting. Diharapkan proses acara pidananya dapat lebih memperhatikan hak-hak korban yang menjadi kejahatan perkosaan. Termasuk juga sarana prasarananya yang mendukung ke efektivitas dalam proses penegakan hukum dan kemampuan yang khusus penegak hukum atau dalam membantu pemulihan korban yang meliputi kesehatan fisik dan psikologisnya (Syaiful, 2010).

Dalam upaya non penal untuk penanggulangan kejahatan seksual, secara komperensif jugam memerlukan langkahlangkah untuk melindungi masyarakat. Kegiatan preventif non penal justru adalah kunci yang harus di efektifkan dan di identifikasikan serta memliki kedudukan yang strategis.

Upaya ini lebih bersifat tindakan preventif, maka dari itu yang utama menjadi sasarannya adalah menganggulangi faktor-faktor kondusif yang menjadi penyebab terjadinya kejahatan. Dapat disebutkan faktor-faktor dari kondusif tersebut yakni yang berpusat pada masalahmasalah atau kondisi sosisal yang dapat dilihat secara langsung atau tidak langsung bisa menyebabkan kejahtaan.

Dalam hal ini pemerintah telah melakukan berbagai cara untuk menaggulangi kejahatan perkosaan baik itu secara penal maupun non penal. Tetapi kenyataannya masih belum efektif. Maka dari itu pemerintah harus kedepannya diperlukan untuk peningkatan dalam langkah-langkah kebijakan masalah kejahatan perkosaan (Arif, 2009).

\section{Simpulan}

Perlindungan hukum terhadap perempuan yang menjadi korban kejatan perkossaan yang selain korban mengalami psikis yang memerlukan waktu yang sangat lama untuk memulihkannya. Penderitaan yang dialami oleh korban tindak pidana perkosaan yang tidak ringan dan memerlukan waktu yang tidak singkat dalam memulihkannya supaya normal seperti sebelumnya, maka dari itu apparat penegak hukum bekewajiban memberikan perlidungan terhadap korban yang diatur dalam peraturan perundang-undangan sebagai produk hukum yang memihaak korban. 2). Dalam penerapan sanski pidana terhadap pelaku tindak pidana perkosaan merupakan cara yang terbaik untuk meneggakan keadilan. Sanksi pidana yang di dapat oleh pelaku tindak pidana perkosaan diatur dalam Pasal 285 KUHP, dimana ketentuan pasal tersebut seseorang yang melakukan tindak pidana perkosaan akan dipidana penjara paling lama 12 tahun. Agar mampu memberikan pelaku efek jera, pelaku 
harus mendapatkan hukuman yang berat.

Kepada aparat penegak hukum dalam memberikan perlindungan dan pelayanan kepada korban yang menjadi tindak pidana perkosaan terutama perempuan sebaiknya dilandasi dengan rasa kemanusiaan dan kepada masyarakat seharusnya ikut juga dalam mendukung para korban perkosaan agar mendapatkan perlindungan hukum sehingga Indonesia dapat menjadi negara yang berhasil untuk mesjahterakan masyrakatnya dengan dilandasi rasa kemanusiaan. Selain itu juga diperlukan peraturan hukum mengenai sanksi pidana yang berat terhadap pelaku dan apparat penegak hukum harus lebih tegas dalam memberikan saknsi hukuman yang dilakukan oleh pelaku kejahatan.

\section{Daftar Pustaka}

Ali, M. (2011). Dasar-Dasar Hukum Pidana. Jakarta: Sinar Grafika.

Arif, G. (2009). Masalah Korban Kejahatan. Jakarta: Universitas Trisakti.

Gosita, A. (2001). Masalah Korban Kejahatan Kumpulan Karangan Edisi Pertama. Jakarta: Akademika Pressindo.

Idran, M. (2011). Tinjauan Yuridis Penerapan Hukum Terhadap Pelaku Tindak Pidana Pemerkosaan Terhadap Anak Kandung. Fiat Justisia Jurnal Ilmu Hukum, 5(3), 410-419. Retrieved from https:// doi.org/10.25041/fiatjustisia.v5no3.336

Ruben, G. R. (2019). Kajian Yuridis Terhadap Tindak Pidana Pemerkosaan Disertai Pembunuhan Anak Di Bawah Umur (Concursus). Lex Crimen, 8(1), 122133. Retrieved from https:// ejournal.unsrat.ac.id/index.php/ lexcrimen/article/view/22696

Sugandhi, R. (1980). KUHP dan Penjelasannya. Surabaya: Usaha Nasional.

Syaiful, B. (2010). Kebijakan Kriminal dalam Perspektif Pembaruan Sistem Peradilan Pidana Indonesia. Yogyakarta: Total Media.

Topo, S. (1997). Seksusalitas dan Hukum Pidana. Jakarta: Hill - Co.

Wahid, A. (2001). Perlindungan Terhadap Korban Seksual. Bandung: Refika Aditama. 